\title{
Animal Models for Small for Gestational Age and Fetal Programing of Adult Disease
}

\author{
Patricia M. Vuguin \\ Department of Pediatrics, Albert Einstein College of Medicine, Bronx, N.Y., USA
}

\section{Key Words}

Intrauterine growth restriction · Small for gestational age • Caloric restriction - Protein restriction $\cdot$ Animal models . Uterine ligation

\begin{abstract}
Fetal growth retardation is a fetal adaptation in response to inadequate supply of oxygen and/or nutrients. Animal models of intrauterine growth retardation are an invaluable tool to question the genetic, molecular and cellular events that determine fetal growth and development. Rodent and nonlitter bearing animals are mammalian system with similar embryology, anatomy and physiology to humans. Utilization of these systems has led to a greater understanding of the pathophysiology and consequences of intrauterine growth retardation. These observations are comparable to that observed in humans born small for gestational age, and are of interest because of the known association between poor fetal growth and development of adult disease. All the experimental manipulations described here have altered a number of metabolic and physiological variables, but the pattern of alterations seems to vary with the procedure and species employed. This review describes animal models for intrauterine growth retardation and assesses their potentials and limitations at aiming to improve strategies for the prevention of adult disease.

Copyright $\odot 2007$ S. Karger AG, Basel
\end{abstract}

\section{Background}

Type 2 diabetes mellitus (T2DM) and the Metabolic Syndrome are modern day plagues of societies in industrialized and developing nations alike [1]. The incidence of both of these diseases has reached epidemic proportions. Cardiovascular disease (CVD) is the leading cause of death in individuals with T2DM. The Metabolic Syndrome is characterized by any two of the following indicators: dyslipidemia, insulin resistance, obesity, impaired glucose tolerance [2]. While animal models [3, 4] (tables 1 and 2), and human epidemiologic studies $[5,6]$ illustrate that genetic and environmental factors play contributory roles in disease incidence and mortality, the underlying molecular mechanisms have been poorly defined. Fetal undernutrition and low birth weight (intrauterine growth restriction [IUGR]) [7-9] have been identified as risk factors for increased incidence of CVD, T2DM or their precursors such as dyslipidemia, impaired glucose tolerance or vascular endothelial dysfunction. Even after controlling for current body mass index, the risk for T2DM has been shown to be elevated among adults with low birth weights, suggesting that fetal programing confers risks above any subsequent environmental influences [10].

The development of disease in adulthood as a consequence of fetal programing was first described by Hales et al. [7-9] in the 'thrifty phenotype' hypothesis. This

Patricia Vuguin, MD, MSc

Division of Pediatric Endocrinology, Children's Hospital at Montefiore Medical Center 111 East 210th Street

Bronx, NY 10476 (USA)

Tel. +1 718920 4664, Fax +1 718405 5609, E-Mail vuguin@aecom.yu.edu 
Table 1. Experimental models of fetal growth restriction

\begin{tabular}{llll}
\hline Interventions & Species & Birth weight & References \\
\hline $\begin{array}{l}\text { Nutritional model } \\
\quad \text { Caloric restriction }\end{array}$ & sheep, pig, and rodent & & $24-56$ \\
$\quad$ LP diet & & decreased & $25,28-39$ \\
$\quad$ dron deficiency & & $40-50$ \\
$\quad$ Over nourishment of adolescent & & $51-52$ \\
$\quad$ pregnant sheep & & & 56 \\
Surgical and hypoxic model & sheep, pig, monkey, & & $4,20,57-75$ \\
Bilateral uterine ligation & guinea pig and rodent & & $4,20,57-60$ \\
$\quad$ Uteroplacental embolization & & decreased & $23,61-66$ \\
$\quad$ Carunclectomy & & decreased & $67-69$ \\
$\quad$ Single umbilical artery ligation & & decreased & $70-73$ \\
$\quad$ Hypoxic chambers & decreased & $74-75$ \\
GC treatment & decreased & $76-99$ \\
Maternal diabetes & rodent, sheep & decreased & $100-104$ \\
Stress & sheep, rodent & decreased (high doses) & increased (low doses) \\
Gene deletion & & decreased & $105-108$ \\
\hline
\end{tabular}

states that when maternal food restriction occurs, changes ensuring energy storage in the fetus take precedence. These changes may have conferred advantages on the fetus but result in disease after birth such as altered metabolic regulation leading to insulin resistance. Some have argued that the genetic variants may explain the association between reduced birth weight and increased risk of T2DM, thus 'thrifty genotype' is the real cause of adult disease [11].

An extension of the thrifty phenotype hypothesis is the 'Predictive Adaptive Response' theory which suggests that the fetus makes adaptations in utero or in an early developmental period based on the predicted postnatal environment [6]. How different the in utero environment is from the postnatal one is an important determinant of disease. The fetal adaptations that occur have been described as metabolic imprinting or programing [12]. This programing occurs within a specific developmental time period when a stimulus or insult results in abnormal development of a somatic structure or the inappropriate 'setting' of a physiological system leading to imbalances in adulthood.

Thus, based on evidence generated over 40 years early nutrition and growth affects CVD in adulthood, but is the prenatal window of growth the only critical period that will develop long-term disease? Increased infant growth rate by an enriched diet for a few weeks postnatally has been shown in observational as well as experimental studies to have a significant effect on CVD [13].
The effect of postnatal growth on cardiovascular complications has been demonstrated by alterations in systolic blood pressure [14], cholesterol [15] and insulin levels [16-18]. Thus, by limiting the consequences of adult disease to prenatal growth, we may be limiting ourselves to a vulnerable period (prenatal) in which intervention may be difficult to achieve. Instead, postnatal factors might be more amenable for targeting interventions making this critical period of growth a possible major contributor to long-term cardiovascular risk. Experimental animal models of IUGR will answer many of these questions.

This review will critically examine the experimental models in use to study IUGR and highlight their respective strengths and weakness.

\section{Underlying Mechanisms}

Experimental models of IUGR (table 1) used either interventions in the mother (limitation of maternal energy and protein intake, uterine blood flow), placenta (function), or in the fetus (genetic manipulation, infections) [3, $4,19]$.

\section{Animal Species Commonly Used in Models of}

Intrauterine Growth Retardation

Various animal species have been used as model of fetal growth retardation. One of the first animal models described by Wigglesworth [20] in 1964 was induction of 
Table 2. Targets of programing

\begin{tabular}{|c|c|c|}
\hline Programing & Species & SGA model \\
\hline $\begin{array}{l}\text { Cardiovascular disease } \\
\text { Hypertension, increase vascular reactivity and } \\
\text { decrease endothelial vasodilatation }\end{array}$ & $\begin{array}{l}\text { guinea pig, rat, } \\
\text { sheep }\end{array}$ & $\begin{array}{l}\text { caloric restriction; LP diet; uterine horn ligation, bilateral } \\
\text { uterine ligation, GC exposure }\end{array}$ \\
\hline $\begin{array}{l}\text { Kidney } \\
\text { Reduction in glomeruli number and filtration rate; } \\
\text { increase apoptosis, and plasma sodium concentration } \\
\text { Suppression of renin and increase angiotensinogen }\end{array}$ & $\begin{array}{l}\text { rat, sheep, } \\
\text { rabbit, piglets } \\
\text { rat, sheep }\end{array}$ & $\begin{array}{l}\text { bilateral uterine ligation, protein restriction, GC exposure } \\
\text { LP diet, caloric restriction, GC exposure }\end{array}$ \\
\hline $\begin{array}{l}\text { Heart } \\
\text { Cardiomyocyte hyperplasia, hypertrophy, and } \\
\text { apoptosis; increase in } \beta 1 \text { adrenoreceptors }\end{array}$ & rat, sheep & $\begin{array}{l}\text { chronic hypoxia, caloric restriction, chronic anemia and } \\
\text { GC exposure }\end{array}$ \\
\hline $\begin{array}{l}\text { Sympathoadrenal system } \\
\text { Increase norepinephrine levels }\end{array}$ & sheep, pig & hypoxemia \\
\hline $\begin{array}{l}\text { Pancreas development } \\
\text { Decrease } \beta \text {-cell mass, proliferation, islet number } \\
\text { and size, insulin content, insulin response to glucose } \\
\text { and amino acids, and blood flow }\end{array}$ & rat & $\begin{array}{l}\text { caloric restriction, LP diet, bilateral uterine ligation, } \\
\text { high dose STZ-induced maternal diabetes }\end{array}$ \\
\hline $\begin{array}{l}\text { Liver } \\
\text { Decrease oxidative phosphorylation, and ATP; } \\
\text { increase gluconeogenesis, altered fatty acid } \\
\text { oxidation, insulin resistance }\end{array}$ & rat & $\begin{array}{l}\text { bilateral uterine ligation, caloric restriction, LP diet, } \\
\text { GC exposure }\end{array}$ \\
\hline $\begin{array}{l}\text { Muscle } \\
\text { Decrease ATP, glycogen, glucose uptake, and muscle } \\
\text { mass; increase triglyceride levels }\end{array}$ & rat & bilateral uterine ligation, LP diet \\
\hline $\begin{array}{l}\text { Adipocyte } \\
\text { Decrease insulin inhibition of lipolysis, higher lipid } \\
\text { content, and hyperleptinemia }\end{array}$ & rat & $\begin{array}{l}\text { LP diet, STZ-induced maternal } \\
\text { diabetes, caloric restriction GC exposure }\end{array}$ \\
\hline $\begin{array}{l}\text { Hypothalamic-pituitary-adrenal axis } \\
\text { Increase corticosterone, alter regulation of the axis, } \\
\text { and increase GC receptor affinity }\end{array}$ & rat, sheep & caloric restriction, GC exposure, LP diet \\
\hline
\end{tabular}

uteroplacental insufficiency by uterine artery ligation in rodents, followed by the use of cigarette smoke during pregnancy in rats in 1969 [21], and experimental placental insufficiency in the rhesus monkey in 1971 [22]. Today, there are more than 1,500 publications using various animal models. Three quarters of them have been performed in rats $(60 \%)$ and mice $(10 \%)$, followed by sheep (12\%), pigs (8\%), guinea pigs (4\%), monkeys (2\%), chick embryos (2\%), and lambs (2\%). (The search phrase in Medline 'animal name + fetal growth retardation', search performed in May 2006.)

Many features of human biology at the cellular and molecular levels are shared with a wide variety of organisms. As mammals, the mouse and rat are highly related to humans, with similar genes, biochemical pathways, organs, and physiology. One of the major limitations is that rodents are altricial animals born with an underdeveloped brain and endocrine/paracrine system with significant maturation of organs during the weaning period. Furthermore, litter-bearing animal models (bearing multiple fetuses) may have a variable nutrient supply among the fetuses from the same litter. The pregnant sheep is a long-standing model for the study of placental-fetal interactions, and fetal growth restriction can be induced in pregnant sheep by maternal nutrient restriction, maternal nutrient excess, administration of glucocorticoids (GC), utero-placental embolization, carunclectomy (excision of uterine epithelium or caruncles) and maternal hyperthermia. Although all of these sheep models are capable of inducing fetal growth re- 
striction, the degree of restriction is variable depending on the breed, maternal nutrition, and the intervention used [23]. Primates are the ideal animal model, but expensive housing, lifespan and ethical considerations limit their use. Thus, careful choice of an animal model is a critical step in the design of any study attempting to answer relevant questions associated with fetal programing.

\section{Interventions}

\section{Nutritional Models}

For over 30 years, nutrient manipulation during pregnancy has been an established model of growth restriction in humans and animal models [24, 25]. Nutritional intervention may mimic the challenge faced in underdeveloped countries. Different strategies have been used global nutrient restriction, isocaloric low-protein (LP) diet, low-iron deficiency and overnutrition at different points during pregnancy. These models are based on the observation that fetal nutrient supply is one of the most important environmental factors affecting pregnancy outcome.

After the nutritional intervention, the animals are fed mainly a standard chow. Some commercially available diets incorporate soy (phytoestrogens) as the source of protein. These phytoestrogens (genestein and diadzein) may have beneficial actions [26,27], lessen the development of CVD programed in utero. Thus, it is feasible that a weaning diet rich in phytoestrogens could reverse or decrease the insult caused by the different nutrient interventions during pregnancy.

\section{Caloric Restriction}

A number of studies have addressed the timing and effect of severe (70\% of ad libitum), moderate $(50 \%)$ and mild caloric restriction (30\%) in various species. The most common dietary intervention has been a $50 \%$ reduction in caloric intake.

In rodents, caloric restriction from days 15 to 21 or from 7 to 21 during pregnancy does not affect length of gestation, litter size or mortality rate but significantly decreases birth weight [28-33]. In contrast, caloric manipulation from 7 to 14 days of gestation does not affect offspring birth weight [25]. Postnatal changes in body weight, body composition and food intake have been associated with both pre- and postnatal diet. Only mild and moderate caloric restriction in utero has been associated with increased catch-up growth postnatally. Obesity and hyperleptinemia have been associated with crossfostering (foster by a healthy mother), overfeeding and postnatal high-fat diet [25].

Caloric restriction programs hypertension, alteration in endothelial vasodilatation, decreased $\beta$-cell mass, islet number and insulin content, decreased insulin response to an oral glucose tolerance test, and hepatic insulin resistance [25].

Relatively few studies have addressed the impact of maternal undernutrition in non-litter-bearing species. The impact of poor fetal nutrition in sheep has been related to the timing of the insult. Maternal malnutrition from early to mid-gestation in fetal sheep leads to decreased maternal weight, fetal growth retardation and cardiac ventricular hypertrophy $[34,35]$, hypertension [36, 37], and blunted endothelial vasodilatation [38]. Similarly, in guinea pigs mild ( $85 \%$ ad libitum) or moderate $(70 \%$ ad libitum) maternal food restriction reduces fetal growth and causes hyperinsulinemia in young adult male offspring [39].

\section{Low-Protein Diet}

Initially described by Snoeck et al. [40] pregnant rats are fed either a normal diet (20\% protein) or an isocaloric LP diet ( $8 \%$ protein), from the first day to until the end of gestation. Protein restriction adversely affects fertilization as well as early egg development and differentiation in mice [41], and alters placental transfer of amino acids in guinea pig [42]. At mid-pregnancy, glucose, insulin, prolactin and progesterone levels are significantly lower in LP mothers compared to control [43]. Litter size does not differ between groups, but LP pups are born IUGR compared to the control.

One advantage of a LP diet is that it can be done in various animal models. LP diet consistently programs hypertension [44], pancreas development, altered insulin response to an oral glucose tolerance test, hepatic insulin resistance and in non-litter-bearing species has been shown to program endothelial dysfunction [45].

One of the major differences between the LP diets is that the composition of the diet elicits different programing effects. Two different LP diets have been commonly used in animal models of fetal programing: The Southampton and the Hope farm diet. The Southampton diet programs hypertension [44], while the Hope farm diet programs insulin resistance [46]. The difference between these diets is the balance of specific amino acids, fat and carbohydrate used. The Southampton diet [44] differs from the Hope farm diet $[46,47]$ in the oil composition 
(soybean vs. corn oil), methionine and carbohydrate content. Amino acids like methionine and glycine are essential compounds for a number of metabolic functions during development such as nucleic acid, collagen and heme formation. Methionine is a major component of the Southampton diet, leading to an excess in comparison to other amino acids. Methionine excess causes hyperhomocystinemia, a known cardiovascular risk factor for the development of endothelial dysfunction. Interestingly, the addition of glycine $[48,49]$ as well as folate reverses the hyperhomocystinemia in animals fed the Southampton diet further suggesting that methionine excess may in part explain the fetal programing observed in this model. Hope farm diet has three times more of the $\omega-3$ polysaturated (PUFA) fatty $\alpha$-linoleic acid than Southampton diet adding a possible cardioprotective advantage. The carbohydrate content should be also assessed because a high glycemic index (Hope farm) may program a different phenotype in addition to the protein restriction. Sodium content is another parameter to be considered before choosing a nutrient modification. Inappropriate sodium intake during pregnancy has been associated with programing of high blood pressure and CVD [50].

\section{Iron Deficiency}

The association between anemia in pregnancy and low birth weight [51] has prompted groups to study the relationship between maternal iron status and the development of adult disease. Animal are fed either a control diet $\left(50 \mathrm{mg} \mathrm{Fe}(\mathrm{kg} \mathrm{diet})^{-1}\right)$ or a Fe-deficient diet $(7.5 \mathrm{mg}$ Fe $(\mathrm{kg}$ diet $)^{-1}$ ) for 4 weeks before mating and through different stages of gestation. Iron deficiency has no effect on maternal weight or litter size, but body weight at birth decreases with the severity of the deficiency [52].

\section{Over-Nourishment of Adolescent Pregnant Sheep}

In Pima Indians the association of birth weight and diabetes is $U$ shaped, with the highest prevalence of diabetes occurring in both high (LGA) and low birth weight infants [53]. Pre-pregnancy obesity seems to be independently and strongly associated with LGA while net weight gain $(5 \mathrm{~kg})$ during pregnancy had a more modest [54], little or no effect on birth weight [55].

Overfeeding single pregnant adolescent dams to promote rapid maternal growth throughout pregnancy is associated with prematurity and poor placenta/fetal growth. The experimental model consists of singleton pubertal adolescent ewes pregnancies that are fed twice their energy requirements. Pregnancies are characterized by placental insufficiency resulting in fetal hypoxia, hypoglycemia, hypoinsulinemia and reduced fetal growth [56].

- Nutrient manipulation during pregnancy, as a cause of IUGR, does not cause frank diabetes, although it does cause CVD.

- Some of the weaknesses of these models are the variability of the outcomes that are in part dependent on the species studied, time of the insult, maternal metabolic environment and body composition before pregnancy.

- The balance of essential amino acids and other nutrients may be critical in determining the metabolic outcome of the offspring.

\section{Surgical and Hypoxic Models}

Surgical interventions have been used to generate a hypoxic model in which growth restriction will affect the placenta and the fetus. Such models are highly relevant to human pregnancy in developed countries. Low oxygen concentrations will generate: fetal hypoxia, increase or decrease amino acid levels, hypoinsulinemia and altered organ growth, factors that cannot be dissociated from each other.

\section{Bilateral Uterine Ligation}

Three-month-old pregnant rats on day 19 of gestational age (term 21.5 days) undergo bilateral uterine artery ligation [20]. Suture is placed around both uterine arteries, then either tied or withd rawn before closing the abdomen. Thirty percent of the fetuses die or undergo partial resorption, especially at the vaginal portion of the horn. Fetuses from bilateral uterine ligation show a $20 \%$ lower body weight compared to control, and the body weights remain significantly diminished even at 21 days of life. Litter size does not differ between groups. Similar to humans, fetal rats in this model suffer transient hypoglycemia, hypoxia, and acidosis, and demonstrate the long-term effects of the altered intrauterine milieu $[57,58]$. These animals exhibit mild insulin resistance and $\beta$-cell secretory defects very early in life $[4$, 59]. Eventually, the $\beta$-cell secretory capacity fails and overt diabetes occurs. A similar model has been used in mice in which fetal growth retardation is induced on 14 day of pregnancy, resulting in a reduction in fetal growth [60]. 


\section{Utero-Placental Embolization}

The pregnant sheep is a long-standing model for placental-fetal interactions, and fetal growth restriction can be induced by utero-placental embolization, carunclectomy or maternal hyperthermia [23]. In sheep, fetal hypoxia ( $50 \%$ of control) has been induced by umbilicoplacental embolization, from 120 days of gestation until term [61, 62]. Embolization is produced by injection of microspheres of $15-30 \mu \mathrm{m}$ in diameter into the fetal or maternal placental vascular bed producing fetal hypoxemia, temporary increase of fetal cortisol and norepinephrine levels [63-66], and growth retardation. During pregnancy IUGR fetuses have lower blood glucose and at birth lambs weigh 33\% less than controls [62].

\section{Carunclectomy}

Carunclectomy is the excision of all visible uterine epithelium caruncles (dark spots in utero) that will determine the number of cotyledons that will generate the placental mass [67]. Placental and fetal weight varies among pregnancy, and fetuses are hypoxemic and hypoglycemic during gestation [67-69]. Thus, it is the small size of the placenta per se rather than alterations in its nutrient transfer or capacity and or hormonal milieu that is the major limitation to fetal growth in the growing adolescent sheep.

\section{Single Umbilical Artery Ligation}

Chronic fetal hypoxia and IUGR can also be experimentally induced by single umbilical artery ligation in catheterized fetal sheep at 105-110 days of gestational age (term mean 147 days). Catheterization causes preterm labor, hypercortisolism and growth retardation [70].

Unilateral artery ligation has also been used in guinea pigs as the preferred method to provide placental insufficiency. The procedure is done at mid-gestation (at 2830 days, term 67 days) causing significant fetal death. The surviving fetuses have either similar or $60 \%$ decreased birth weight $[71,72]$. IUGR fetuses are hypoglycemic, hypoinsulinemic, hypocortisolemic with elevated glucagon [72], insulin growth factor-binding globulin (IGFBP)-2 and -4 , and reduced IGFBP-3 levels [73].

\section{Hypoxic Chambers}

Another model of hypoxia is the acute or chronic exposure of pregnant rats to lower oxygen concentration (9.5-14\% vs. $21 \%$ in controls) in specially designed chambers. Independently of the duration of the hypoxic insult, genes related to calcium homeostasis and cytoskeleton are consistently up-regulated and genes related to G-pro- tein signaling, growth, and ion transport are consistently down-regulated in all tissues. Acute hypoxia is associated with up-regulation of hexokinase, phosphofructokinase, and aldolase while chronic hypoxia is associated with up-regulation of inflammation-related genes [74]. Fetuses have lower body weight compared to controls. Lower oxygen concentration or chronic hypoxia results in decreased daily food intake (similar to models of caloric restriction), litter size and severe growth retardation $[74,75]$.

- A major advantage of the surgical model is that the maternal metabolic environment and body composition before and during pregnancy will not affect the fetal outcome.

- Surgical manipulations are particularly useful in large animal models, such as sheep, since the outcome can be monitored in a viable fetus. In small animals 30\% of the fetus either die or undergo partial resorption.

- Bilateral uterine artery ligation provides the only model that develops frank diabetes, due to the association between insulin resistance and $\beta$-cell secretory defects.

- It is possible that surgical manipulations could be used in conjunction with the other models to further elucidate the effect of the maternal versus the placental milieu on fetal growth.

\section{Glucocorticoids Model}

Maternal exposure to GC has been associated with reduced birth weight and adult disease in both humans and animals models [76-81]. In humans, the effects of prenatal GC exposure are not clear. Impaired fetal growth was not identified in the original randomized trials of prenatal GC given for fetal lung maturation [82]. Other studies have demonstrated an association between repeated administration of antenatal corticosteroids and impaired fetal growth in preterm [83-85] and term infants [86]. Exposure to multiple courses of antenatal corticosteroids compared with a single course resulted in a reduction in birth head circumference with no alteration in birth weight [87]. Thus, the National Institutes of Health (NIH) published in 2000 a consensus statement that reaffirmed the safety and efficacy of a single course of antenatal steroids, but emphasized that there are no data to support the safety and efficacy of repeated courses.

In animals, the effect on birth weight is more notable with increasing number of GC courses $[84,88]$ or when 
given in the latter stages of pregnancy [76]. The exposure to natural (cortisol) or synthetic GC (dexamethasone or betamethasone) does not necessarily have the same long-term consequences in the offspring [89]. Dexamethasone treatment but not cortisone acetate (not the natural GC of rodents) or betamethasone causes hypertension in the adult offspring. Furthermore, the long-term effect of GC may vary among species or sex [90]. In adult female the hypothalamo-lactotroph axis is profoundly affected suggesting a sex-specific effect by perinatal exposure to GC [90]. Maternal administration of betamethasone, but not cortisol, causes decreased fetal growth in lambs [91]. In long-gestation mammals (sheep or humans) the timing of the insult is more important than the type of GC excess [92]. Early exposure of GC in the ewe has been associated with adult hypertension [93-95]. In contrast, late exposure during gestation to GC is associated with insulin resistance but not hypertension [79]. Interestingly, excessive prenatal GC exposure may also be a result of caloric/ protein restriction models, suggesting that mothers who are stressed during a particular stage of pregnancy may predispose the offspring to adult disease [92]. Some of the protocol in use are: intraperitoneal injections of dexamethasone $(0.2 \mathrm{mg} / \mathrm{kg}$ body weight), or via the mothers' drinking water $(1 \mu \mathrm{g} / \mathrm{ml})$ to pregnant rats from gestational day $11[90,96]$, or betamethasone (50$600 \mu \mathrm{g} / \mathrm{kg}$ per day, subcutaneously) from gestational day 15-21 [97], or hydrocortisone acetate $(1.5 \mathrm{mg} /$ day/ animal, subcutaneously) from day 17 to 19 of pregnancy [98]. Similarly to corticosteroids, prenatal bi-weekly testosterone treatment $(100 \mathrm{mg})$ to pregnant sheep between 30 and 90 days of gestation produces growth-retarded offspring [99].

- The impact of exposure of the fetus to GC depends on: dose and type of GC, window of exposure, sex and stage of development of the developing fetus, and animal model, suggesting that part of differences in the outcome may be related to the critical window of development of each organ, species and sex. Whether this is the case in humans awaits long-term follow-up of children enrolled in randomized controlled trials of prenatal GC therapy.

\section{Maternal Diabetes}

Uncontrolled maternal diabetes is characterized by an abnormal intrauterine milieu that results in alterations in growth and development of the fetus [100-104].
The dose of streptozotocin (STZ) may be critical in determining the metabolic outcome of the offspring.

- Diabetes is induced by administration of STZ to either rats or sheep. This method has been used to elucidate the effect of diabetes on fetal growth and development. A major drawback is that the phenotype of the offspring is related to the dose of STZ used during pregnancy. Low dose of STZ results in mild gestational diabetes and fetal macrosomia, whereas a high dose induces insulin deficiency diabetes-associated growth restriction.

\section{Stress-Induced Fetal Growth Restriction}

Stress interferes with reproduction, and has been demonstrated to adversely influence fetal growth. Maternal stress has been induced by placement of pregnant females for $45 \mathrm{~min}$ in a transparent plastic cylinder three times per day [105], or by exposure to sound (100 dB, random frequency between 9 and $34 \mathrm{kHz}$ ) for $8 \mathrm{~h}$ three times during pregnancy, or by housing for $\sim 85$ consecutive days in a heat chamber in which the temperature reached $40^{\circ} \mathrm{C}$ [106], or by maternal restraint $[107,108]$.

\section{Other Maternal Models}

Fetal alcohol exposure causes reduced birth weight. Animal models of fetal alcohol growth restriction include inhalation of ethanol vapor and intraperitoneal injection, as well as oral exposure by gavage, diet, or drinking water [109]. Inhalation of tobacco on days 3-22 of gestational age [21], renal insufficiency [110], partial nephrectomy on day 14 of gestational age [111], and maternal thyroidectomy [112].

\section{Fetal and Genetic Interventions}

Several manipulations at the level of the fetus have been described as possible models for growth restriction like transplacental infection at day 12.5 of gestation by direct injection of cytomegalovirus [113]; or pancreatectomy of sheep fetuses [114]. Gene deletions in mouse models have also been associated with IUGR, e.g. pleomorphic adenoma gene 1 proto-oncogene [115], insulin receptor substrate-1 [116], placental specific knockout of a single imprinted gene encoding insulin-like growth factor (IGF)-2 [117], total ablation of the glucagon receptor 
[118], ablation of the scaffold attachment factor B1 [119], testicular orphan nuclear receptor 4 [120], IGF-2 mRNAbinding protein 1 [121], insulin receptor and insulin gene, and IGF-1 and -2 [122], IGF-1 receptor [123], and IGFBP1 overexpression [124].

\section{Conclusions}

In conclusion, animal models of growth restriction are an effective and valuable tool in understanding the relationship between fetal growth and adult disease. All the experimental models have produced useful information into the basic mechanism underlying fetal growth, and are necessary for the advancement of the field as well as to prevent the development of disease. While we cannot substitute for the study of human disease, animal models of growth restriction provide a useful tool that allows the utilization of techniques that would be unethical in humans. The caveat of in vivo research lies in the observation that the majority of animal models manifest most but not all the symptoms seen in humans; frank disease is not easily reproducible. A possible explanation is that the critical window for programing is different among the species. Further, the maternal hormonal milieu, pla- cental function and fetus response to the insult may vary among species and techniques used to generate growth restriction. Some have argued that the 'thrifty phenotype' may be due to a 'thrifty genotype' and that genetic variants may explain the association between reduced birth weight and T2DM, suggesting that programing is more a risk factor than a causal event in the history of T2DM. Thus, as the developmental origin of adult disease field expands we need to balance the contribution of the thrifty phenotype and the thrifty genotype in the generation of disease, and determine their respective role in the different outcomes. Therefore, we may conclude that though, none of the models currently available are totally satisfactory, because of the possible confounding variables that may play a role in the pathogenesis of fetal growth restriction (e.g. genetic vs. environment), the challenge is to fully understand in detail the specific mechanism that leads to metabolic disease in the offspring.

\section{Acknowledgement}

Dr. Vuguin is a recipient of the National Institute of Health KO8 HD042172 award.

\section{References}

1 Ludwig DS, Ebbeling CB: Type 2 diabetes mellitus in children: primary care and public health considerations. JAMA 2001;286: 1427-1430.

2 Bertram C, Hanson MA: Animals models and programming of the metabolic syndrome. Br Med Bull 2001;60:103-121.

3 Ozanne SE: Metabolic programming in animals. Br Med Bull 2001;60:143-152.

$\checkmark 4$ Vuguin P: Animals models for assessing the consequences of intrauterine growth retardation on subsequent glucose metabolism of the offspring: a review. J Matern Fetal Neonatal Med 2002;254-257.

5 Gluckman PD, Cutfield W, Hofman P, Hanson MA: The fetal, neonatal, and infant environments-the long-term consequences for disease risk. Early Hum Dev 2005;81:51-59.

-6 Gluckman PD, Hanson MA: Maternal constraint of fetal growth and its consequences. Semin Fetal Neonatal Med 2004;9:419-425.

7 Hales CN, Ozanne SE: For debate: fetal and early postnatal growth restriction lead to diabetes, the metabolic syndrome and renal failure. Diabetologia 2003;46:1013-1019.

$\checkmark 8$ Hales CN: Early programming of glucose metabolism, insulin action and longevity. Adv Exp Med Biol 2000;478:57-64. $\checkmark 9$ Hales C, Barker D, Clark P, Cox L, Fall C, Osmond C: Fetal and infant growth and impaired glucose tolerance at age 64 years. $\mathrm{Br}$ Med 1991;303:1019-1022.

10 Rich-Edwards J, Colditz G, Stampfer M, et al: Birthweight and the risk for type 2 diabetes mellitus in adult women. Ann Intern Med 1999;130:278-284.

11 Drake AJ, Walker BR: The intergenerational effects of fetal programming: non-genomic mechanisms for the inheritance of low birth weight and cardiovascular risk. J Endocrinol 2004;180:1-16.

12 Lucas A, Morley R: Birthweight ratio. Arch Dis Child 1991;66:1099.

13 Singhal A, Lucas A: Early origins of cardiovascular disease: is there a unifying hypothesis? Lancet 2004;363:1642-1645.

14 Singhal A, Cole TJ, Lucas A: Early nutrition in preterm infants and later blood pressure: two cohorts after randomised trials. Lancet 2001;357:413-419.

15 Singhal A, Cole TJ, Fewtrell M, Lucas A: Breastmilk feeding and lipoprotein profile in adolescents born preterm: follow-up of a prospective randomised study. Lancet 2004; 363:1571-1578.
16 Srinivasan M, Laychock SG, Hill D, Patel M: Neonatal nutrition: metabolic programming of pancreatic islets and obesity. Exp Biol Med 2003;228:15-23.

17 Beierle EA, Chen MK, Hartwich JE, et al: Artificial rearing of mouse pups: development of a mouse pup in a cup model. Pediatr Res 2004;56:250-255.

18 Singhal A, Fewtrell M, Cole TJ, Lucas A: Low nutrient intake and early growth for later insulin resistance in adolescents born preterm. Lancet 2003;361:1089-1097.

19 Petry CJ, Ozanne SE, Hales CN: Programming of intermediary metabolism. Mol Cell Endocrinol 2001;185:81-91.

20 Wigglesworth JS: Experimental growth retardation in the foetal rat. J Pathol Bacteriol 1964;88:1-13.

21 Younoszai MK, Peloso J, Haworth JC: Fetal growth retardation in rats exposed to cigarette smoke during pregnancy. Am J Obstet Gynecol 1969;104:1207-1213.

- 22 Hill DE, Myers RE, Holt AB, Scott RE, Cheek DB: Fetal growth retardation produced by experimental placental insufficiency in the rhesus monkey. II. Chemical composition of the brain, liver, muscle and carcass. Biol Neonate 1971;19:68-82. 
-23 Anthony RV, Scheaffer AN, Wright CD, Regnault TR: Ruminant models of prenatal growth restriction. Reprod Suppl 2003;61: 183-194.

24 Villar J, Belizan JM: The timing factor in the pathophysiology of the intrauterine growth retardation syndrome. Obstet Gynecol Surv 1982;37:499-506.

-25 Ergaz Z, Avgil M, Ornoy A: Intrauterine growth restriction-etiology and consequences: what do we know about the human situation and experimental animal models? Reprod Toxicol 2005;20:301-322.

26 Gardner JD, Brower GL, Janicki JS: Effects of dietary phytoestrogens on cardiac remodeling secondary to chronic volume overload in female rats. J Appl Physiol 2005;99:13781383.

-27 Mahn K, Borras C, Knock GA, et al: Dietary soy isoflavone induced increases in antioxidant and eNOS gene expression lead to improved endothelial function and reduced blood pressure in vivo. FASEB J 2005; 19: 1755-1757.

28 Garofano A, Czernichow P, Breant B: In utero undernutrition impairs rat beta-cell development. Diabetologia 1997;40:12311234.

29 Garofano A, Czernichow P, Breant B: Postnatal somatic growth and insulin contents in moderate or severe intrauterine growth retardation in the rat. Biol Neonate 1998;73: 89-98.

30 Garofano A, Czernichow P, Breant B: Agedependent inability of the endocrine pancreas to adapt to pregnancy: a long-term consequence of perinatal malnutrition in the rat. Endocrinology 1999;140:4208-4213.

- 31 Jimenez-Chillaron JC, Hernandez-Valencia $\mathrm{M}$, Reamer C, et al: Beta-cell secretory dysfunction in the pathogenesis of low birth weight-associated diabetes: a murine model. Diabetes 2005;54:702-711.

- 32 Ozaki T, Nishina H, Hanson MA, Poston L: Dietary restriction in pregnant rats causes gender-related hypertension and vascular dysfunction in offspring. J Physiol 2001;530: 141-152.

- 33 Vickers MH, Breier BH, Cutfield WS, Hofman PL, Gluckman PD: Fetal origins of hyperphagia, obesity, and hypertension and postnatal amplification by hypercaloric nutrition. Am J Physiol Endocrinol Metab 2000;279:E83-E87.

- 34 Han HC, Austin KJ, Nathanielsz PW, Ford SP, Nijland MJ, Hansen TR: Maternal nutrient restriction alters gene expression in the ovine fetal heart. J Physiol 2004;558:111121.

35 Vonnahme KA, Hess BW, Hansen TR, et al: Maternal undernutrition from early- to midgestation leads to growth retardation, cardiac ventricular hypertrophy, and increased liver weight in the fetal sheep. Biol Reprod 2003;69:133-140.
36 Edwards LJ, McMillen IC: Periconceptional nutrition programs development of the cardiovascular system in the fetal sheep. Am J Physiol Regul Integr Comp Physiol 2002; 283:R669-R679.

37 Hawkins P, Steyn C, McGarrigle HH, et al: Cardiovascular and hypothalamic-pituitary-adrenal axis development in late gestation fetal sheep and young lambs following modest maternal nutrient restriction in early gestation. Reprod Fertil Dev 2000;12:443456.

38 Ozaki T, Hawkins P, Nishina H, Steyn C, Poston L, Hanson MA: Effects of undernutrition in early pregnancy on systemic small artery function in late-gestation fetal sheep. Am J Obstet Gynecol 2000;183:1301-1307.

39 Kind KL, Clifton PM, Grant PA, et al: Effect of maternal feed restriction during pregnancy on glucose tolerance in the adult guinea pig. Am J Physiol Regul Integr Comp Physiol 2003;284:R140-R152.

40 Snoeck A, Remacle C, Reusens B, Hoet J: Effect of a low protein diet during pregnancy on the fetal rat endocrine pancreas. Biol Neonate 1990;57:107-118.

-41 Munoz G, Bongiorni-Malave I: Influence of dietary protein restriction on ovulation, fertilization rates and pre-implantation embryonic development in mice. J Exp Zool 1979; 210:253-257.

42 Young M, Widdowson EM: The influence of diets deficient in energy, or in protein, on conceptus weight, and the placental transfer of a non-metabolisable amino acid in the guinea pig. Biol Neonate 1975;27:184-191.

-43 Fernandez-Twinn DS, Ozanne SE, Ekizoglou S, et al: The maternal endocrine environment in the low-protein model of intrauterine growth restriction. Br J Nutr 2003; 90:815-822.

44 Langley SC, Jackson AA: Increased systolic blood pressure in adult rats induced by fetal exposure to maternal low protein diets. Clin Sci (Lond) 1994;86:217-222; discussion 121.

45 Nishina $\mathrm{H}$, Green LR, McGarrigle HH, Noakes DE, Poston L, Hanson MA: Effect of nutritional restriction in early pregnancy on isolated femoral artery function in mid-gestation fetal sheep. J Physiol 2003;553:637647.

46 Lucas A, Baker BA, Desai M, Hales CN: Nutrition in pregnant or lactating rats programs lipid metabolism in the offspring. Br J Nutr 1996;76:605-612.

47 Ozanne SE, Wang CL, Dorling MW, Petry CJ: Dissection of the metabolic actions of insulin in adipocytes from early growth-retarded male rats. J Endocrinol 1998;162:313319.

48 Jackson AA, Dunn RL, Marchand MC, Langley-Evans SC: Increased systolic blood pressure in rats induced by a maternal lowprotein diet is reversed by dietary supplementation with glycine. Clin Sci (Lond) 2002;103:633-639.
49 Brawley L, Torrens C, Anthony FW, et al: Glycine rectifies vascular dysfunction induced by dietary protein imbalance during pregnancy. J Physiol 2004;554:497-504.

50 Contreras RJ, Wong DL, Henderson R, Curtis KS, Smith JC: High dietary $\mathrm{NaCl}$ early in development enhances mean arterial pressure of adult rats. Physiol Behav 2000;71: 173-181.

51 Scholl TO, Hediger ML: Anemia and irondeficiency anemia: compilation of data on pregnancy outcome. Am J Clin Nutr 1994; 59:492S-500S; discussion 500S-501S.

52 Gambling L, Andersen HS, Czopek A, Wojciak R, Krejpcio Z, McArdle HJ: Effect of timing of iron supplementation on maternal and neonatal growth and iron status of irondeficient pregnant rats. J Physiol 2004;561: 195-203.

53 McCance DR, Pettitt DJ, Hanson RL, Jacobsson LT, Knowler WC, Bennett PH: Birth weight and non-insulin dependent diabetes: thrifty genotype, thrifty phenotype, or surviving small baby genotype? BMJ 1994;308: 942-945.

54 Ray JG, Vermeulen MJ, Shapiro JL, Kenshole $\mathrm{AB}$ : Maternal and neonatal outcomes in pregestational and gestational diabetes mellitus, and the influence of maternal obesity and weight gain: the DEPOSIT study. Diabetes Endocrine Pregnancy Outcome Study in Toronto. QJM 2001;94:347-356.

55 Kirchengast S, Hartmann B, Schweppe KW, Husslein P: Impact of maternal body build characteristics on newborn size in two different European populations. Hum Biol 1998;70:761-774.

56 Wallace JM, Luther JS, Milne JS, et al: Nutritional modulation of adolescent pregnancy outcome - a review. Placenta 2006;27(suppl A):S61-S68.

57 Simmons R, Gounis A, Bangalore S, Ogata E: Intrauterine growth retardation: Fetal glucose transport is diminished in lung but spared in brain. Pediatr Res 1991;31:59-63.

58 Ogata E, Bussey M, Finley S: Altered gas exchange, limited glucose, branched chain amino acids, and hypoinsulinism retard fetal growth in the rat. Metabolism 1986;35: 970-977.

59 Vuguin P, Raab E, Liu B, Barzilai N, Simmons R: Hepatic insulin resistance precedes the development of diabetes in a model of intrauterine growth retardation. Diabetes 2004;53:2617-2622.

60 Aalinkeel R, Srinivasan M, Kalhan SC, Laychock SG, Patel MS: A dietary intervention (high carbohydrate) during the neonatal period causes islet dysfunction in rats. Am J Physiol 1999;277:E1061-E1069.

61 Duncan JR, Cock ML, Loeliger M, Louey S, Harding R, Rees SM: Effects of exposure to chronic placental insufficiency on the postnatal brain and retina in sheep. J Neuropathol Exp Neurol 2004;63:1131-1143. 
62 Louey S, Cock ML, Stevenson KM, Harding R: Placental insufficiency and fetal growth restriction lead to postnatal hypotension and altered postnatal growth in sheep. Pediatr Res 2000;48:808-814.

-63 Creasy RK, Barrett CT, de Swiet M, Kahanpaa KV, Rudolph AM: Experimental intrauterine growth retardation in the sheep. Am J Obstet Gynecol 1972;112:566-573.

-64 Gagnon R, Challis J, Johnston L, Fraher L: Fetal endocrine responses to chronic placental embolization in the late-gestation ovine fetus. Am J Obstet Gynecol 1994;170:929938.

65 Trudinger BJ, Stevens D, Connelly A, et al: Umbilical artery flow velocity waveforms and placental resistance: the effects of embolization of the umbilical circulation. Am J Obstet Gynecol 1987;157:1443-1448.

-66 Charlton V, Johengen M: Fetal intravenous nutritional supplementation ameliorates the development of embolization-induced growth retardation in sheep. Pediatr Res 1987;22:55-61.

-67 Jones CT, Gu W, Harding JE, Price DA, Parer JT: Studies on the growth of the fetal sheep. Effects of surgical reduction in placental size, or experimental manipulation of uterine blood flow on plasma sulphation promoting activity and on the concentration of insulin-like growth factors I and II. J Dev Physiol 1988;10:179-189.

68 Robinson JS, Kingston EJ, Jones CT, Thorburn GD: Studies on experimental growth retardation in sheep. The effect of removal of a endometrial caruncles on fetal size and metabolism. J Dev Physiol 1979;1:379-398.

-69 Butler TG, Schwartz J, McMillen IC: Differential effects of the early and late intrauterine environment on corticotrophic cell development. J Clin Invest 2002;110:783-791.

-70 Supramaniam VG, Jenkin G, Loose J, Wallace EM, Miller SL: Chronic fetal hypoxia increases activin A concentrations in the latepregnant sheep. BJOG 2006;113:102-109.

71 Lafeber HN, Rolph TP, Jones CT: Studies on the growth of the fetal guinea pig. The effects of ligation of the uterine artery on organ growth and development. J Dev Physiol 1984;6:441-459.

-72 Jones CT, Lafeber HN, Roebuck MM: Studies on the growth of the fetal guinea pig. Changes in plasma hormone concentration during normal and abnormal growth. J Dev Physiol 1984;6:461-472.

-73 Carter AM, Kingston MJ, Han KK, Mazzuca DM, Nygard K, Han VK: Altered expression of IGFs and IGF-binding proteins during intrauterine growth restriction in guinea pigs. J Endocrinol 2005;184:179-189.

74 Huang ST, Vo KC, Lyell DJ, et al: Developmental response to hypoxia. FASEB J 2004; 18:1348-1365.
75 Tapanainen PJ, Bang P, Wilson K, Unterman TG, Vreman HJ, Rosenfeld RG: Maternal hypoxia as a model for intrauterine growth retardation: effects on insulin-like growth factors and their binding proteins. Pediatr Res 1994;36:152-158.

76 Nyirenda MJ, Lindsay RS, Kenyon CJ, Burchell A, Seckl JR: Glucocorticoid exposure in late gestation permanently programs rat hepatic phosphoenolpyruvate carboxykinase and glucocorticoid receptor expression and causes glucose intolerance in adult offspring. J Clin Invest 1998;101:2174-2181.

77 Newnham JP, Moss TJ: Antenatal glucocorticoids and growth: single versus multiple doses in animal and human studies. Semin Neonatol 2001;6:285-292.

78 Newnham JP: Is prenatal glucocorticoid administration another origin of adult disease? Clin Exp Pharmacol Physiol 2001;28:957961.

79 Moss TJ, Sloboda DM, Gurrin LC, Harding R, Challis JR, Newnham JP: Programming effects in sheep of prenatal growth restriction and glucocorticoid exposure. Am J Physiol Regul Integr Comp Physiol 2001;281: R960-R970.

80 Johnson JW, Mitzner W, London WT, Palmer AE, Scott R: Betamethasone and the rhesus fetus: multisystemic effects. Am J Obstet Gynecol 1979;133:677-684.

81 Reinisch JM, Simon NG, Karow WG, Gandelman R: Prenatal exposure to prednisone in humans and animals retards intrauterine growth. Science 1978;202:436-438.

82 Collaborative Group on Antenatal Steroid Therapy: Effects of antenatal dexamethasone administration in the infant: long-term follow-up. J Pediatr 1984;104:259-267.

83 Bloom SL, Sheffield JS, McIntire DD, Leveno KJ: Antenatal dexamethasone and decreased birth weight. Obstet Gynecol 2001;97:485490.

84 French NP, Hagan R, Evans SF, Godfrey M, Newnham JP: Repeated antenatal corticosteroids: size at birth and subsequent development. Am J Obstet Gynecol 1999;180:114121.

85 Rodriguez-Pinilla E, Prieto-Merino D, Dequino G, Mejias C, Fernandez P, MaryinezFrias M; Grupo del ECEMC: Antenatal exposure to corticosteroids for fetal lung maturation and its repercussion on weight, length and head circumference in the newborn infant (Spanish). Med Clin 2006;127: 361-367.

86 Murphy DJ, Caukwell S, Joels LA, Wardle P: Cohort study of the neonatal outcome of twin pregnancies that were treated with prophylactic or rescue antenatal corticosteroids. Am J Obstet Gynecol 2002;187:483-488.

87 Abbasi S, Hirsch D, Davis J, et al: Effect of single versus multiple courses of antenatal corticosteroids on maternal and neonatal outcome. Am J Obstet Gynecol 2000;182: 1243-1249.
88 Pratt L, Magness RR, Phernetton T, Hendricks SK, Abbott DH, Bird IM: Repeated use of betamethasone in rabbits: effects of treatment variation on adrenal suppression, pulmonary maturation, and pregnancy outcome. Am J Obstet Gynecol 1999; 180:995-1005.

89 Dodic M, McAlinden AT, Jefferies AJ, et al: Differential effects of prenatal exposure to dexamethasone or cortisol on circulatory control mechanisms mediated by angiotensin II in the central nervous system of adult sheep. J Physiol 2006;571:651-660.

$\checkmark 90$ McArthur S, Siddique ZL, Christian HC, et al: Perinatal glucocorticoid treatment disrupts the hypothalamo-lactotroph axis in adult female, but not male, rats. Endocrinology 2006;147:1904-1915.

-91 Jobe AH, Newnham JP, Moss TJ, Ikegami M: Differential effects of maternal betamethasone and cortisol on lung maturation and growth in fetal sheep. Am J Obstet Gynecol 2003;188:22-28.

92 Moritz KM, Boon WM, Wintour EM: Glucocorticoid programming of adult disease. Cell Tissue Res 2005;322:81-88.

$\checkmark 93$ Dodic M, Hantzis V, Duncan J, et al: Programming effects of short prenatal exposure to cortisol. FASEB J 2002;16:10171026.

$\$ 94$ Dodic M, Abouantoun T, O’Connor A, Wintour EM, Moritz KM: Programming effects of short prenatal exposure to dexamethasone in sheep. Hypertension 2002; 40:729-734.

$\checkmark 95$ Dodic M, May CN, Wintour EM, Coghlan JP: An early prenatal exposure to excess glucocorticoid leads to hypertensive offspring in sheep. Clin Sci (Lond) 1998;94: 149-155.

\$6 Ortiz LA, Quan A, Zarzar F, Weinberg A, Baum M: Prenatal dexamethasone programs hypertension and renal injury in the rat. Hypertension 2003;41:328-334.

$\checkmark 9$ McDonald TJ, Franko KL, Brown JM, Jenkins SL, Nathanielsz PW, Nijland MJ: Betamethasone in the last week of pregnancy causes fetal growth retardation but not adult hypertension in rats. J Soc Gynecol Investig 2003;10:469-473.

$\checkmark 98$ Piffer RC, Pereira OC: Reproductive aspects in female rats exposed prenatally to hydrocortisone. Comp Biochem Physiol C Toxicol Pharmacol 2004;139:11-16.

$\checkmark 99$ Manikkam M, Crespi EJ, Doop DD, et al: Fetal programming: prenatal testosterone excess leads to fetal growth retardation and postnatal catch-up growth in sheep. Endocrinology 2004;145:790-798.

100 Canavan JP, Goldspink DF: Maternal diabetes in rats. II. Effects on fetal growth and protein turnover. Diabetes 1988;37:16711677.

101 Eriksson UJ, Lewis NJ, Freinkel N: Growth retardation during early organogenesis in embryos of experimentally diabetic rats. Diabetes 1984;33:281-284. 
102 Eriksson UJ, Jansson L: Diabetes in pregnancy: decreased placental blood flow and disturbed fetal development in the rat. Pediatr Res 1984;18:735-738.

103 Eriksson UJ: Diabetes in pregnancy: retarded fetal growth, congenital malformations and feto-maternal concentrations of zinc, copper and manganese in the rat. J Nutr 1984;114:477-484.

104 Holemans K, Aerts L, Van Assche FA: Fetal growth restriction and consequences for the offspring in animal models. J Soc Gynecol Investig 2003;10:392-399.

105 Lesage J, Del-Favero F, Leonhardt M, et al: Prenatal stress induces intrauterine growth restriction and programmes glucose intolerance and feeding behaviour disturbances in the aged rat. J Endocrinol 2004;181:291296.

106 Thureen PJ, Trembler KA, Meschia G, Makowski EL, Wilkening RB: Placental glucose transport in heat-induced fetal growth retardation. Am J Physiol 1992;263:R578R585.

$\checkmark 107$ Rasco JF, Hood RD: Differential effect of restraint procedure on incidence of restraint-stress-induced rib fusion in CD-1 mice. Toxicol Lett 1994;71:177-182.

108 Rasco JF, Hood RD: Effects of maternal restraint stress and sodium arsenate in mice. Reprod Toxicol 1994;8:49-54.

-109 Ponnappa BC, Rubin E: Modeling alcohol's effects on organs in animal models. Alcohol Res Health 2000;24:93-104.
110 Nitzan M, Orloff S, Chrzanowska BL, Schulman JD: Intrauterine growth retardation in renal insufficiency: an experimental model in the rat. Am J Obstet Gynecol 1979; 133:40-43.

111 Ishimoto H, Natori M, Tanaka M, Miyazak T, Kobayashi T, Yoshimura Y: Role of oxygen-derived free radicals in free growth retardation induced by ischemia-reperfusion in rats. Am J Physiol 1997;272:H701H705.

112 Pickard MR, Leonard AJ, Ogilvie LM, et al: Maternal hypothyroidism in the rat influences placental and liver glycogen stores: fetal growth retardation near term is unrelated to maternal and placental glucose metabolic compromise. J Endocrinol 2003; 176:247-255.

113 Li RY, Tsutsui Y: Growth retardation and microcephaly induced in mice by placental infection with murine cytomegalovirus. Teratology 2000;62:79-85.

114 Fowden AL, Hughes P, Comline RS: The effects of insulin on the growth rate of the sheep fetus during late gestation. Q J Exp Physiol 1989;74:703-714.

115 Hensen K, Braem C, Declercq J, et al: Targeted disruption of the murine Plag1 protooncogene causes growth retardation and reduced fertility. Dev Growth Differ 2004; 46:459-470.

116 Tamemoto H, Kadowaki T, Tobe K, et al: Insulin resistance and growth retardation in mice lacking insulin receptor substrate1. Nature 1994;372:182-186.
117 Sibley CP, Turner MA, Cetin I, et al: Placental phenotypes of intrauterine growth. Pediatr Res 2005;58:827-832.

118 Vuguin PM, Kedees MH, Cui L, et al: Ablation of the glucagon receptor gene increases fetal lethality, and produces alterations in islet development and maturation. Endocrinology 2006;147:3995-4006.

119 Ivanova M, Dobrzycka KM, Jiang S, et al: Scaffold attachment factor B1 functions in development, growth, and reproduction. Mol Cell Biol 2005;25:2995-3006.

120 Collins LL, Lee YF, Heinlein CA, et al: Growth retardation and abnormal maternal behavior in mice lacking testicular orphan nuclear receptor 4. Proc Natl Acad Sci USA 2004;101:15058-15063.

121 Hansen TV, Hammer NA, Nielsen J, et al: Dwarfism and impaired gut development in insulin-like growth factor II mRNAbinding protein 1-deficient mice. Mol Cell Biol 2004;24:4448-4464.

122 Lupu F, Terwilliger JD, Lee K, Segre GV, Efstratiadis A: Roles of growth hormone and insulin-like growth factor 1 in mouse postnatal growth. Dev Biol 2001;229:141-162.

123 Nakae J, Kido Y, Accili D: Distinct and overlapping functions of insulin and IGF-I receptors. Endocr Rev 2001;22:818-835.

124 Crossey PA, Pillai CC, Miell JP: Altered placental development and intrauterine growth restriction in IGF binding protein-1 transgenic mice. J Clin Invest 2002;110: 411-418. 